RESIDENT

\& FELLOW

SECTION

Section Editor

Mitchell S.V. Elkind,

MD, MS

Paramdeep Singh, MD

Kavita Saggar, MD

Archana Ahluwalia, MD

Parambir Sandhu, MD

Address correspondence and reprint requests to Dr. Paramdeep Singh, Department of

Radiodiagnosis, Dayanand

Medical College \& Hospital,

Ludhiana-141001, Punjab, India paramdeepdoctor@gmail.com

\title{
Teaching NeuroImages: \\ Megaloencephalic leukoencephalopathy with subcortical cysts (Van der Knaap disease)
}

Figure MRI features of megaloencephalic leukoencephalopathy

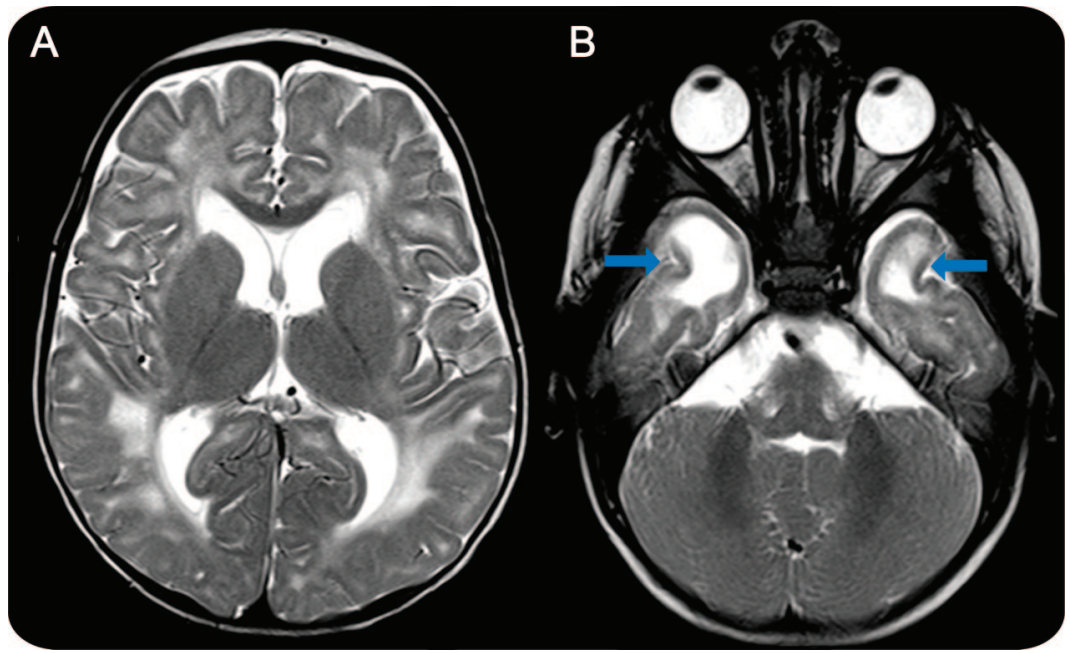

(A) Axial T2-weighted image showing diffusely abnormal (hyperintense) and mildly swollen white matter with sparing of basal ganglia, thalami, and internal capsules. (B) Axial T2-weighted image showing subcortical cysts (arrows) in the bilateral anterior temporal lobes. Cerebellum and brainstem are normal.

A 9-month-old boy born at full term to consanguineous parents presented with seizures, macrocephaly, and inability to sit without support. MRI showed characteristic features ${ }^{1,2}$ (figure) establishing the diagnosis of megaloencephalic leukoencephalopathy (MLC). MLC is an autosomal recessive, neurodegenerative disorder with macrocephaly in the first year of life but delayed onset of motor deterioration and cognitive decline despite markedly abnormal MRI findings. ${ }^{1}$ The differential diagnosis of MLC includes Canavan disease, Alexander disease, L-2- hydroxyglutaric aciduria, and merosin-deficient congenital muscular dystrophy. None of these disorders shares all the MRI features, clinical characteristics, and disease course of MLC. ${ }^{1}$

\section{REFERENCES}

1. van der Knaap MS, Barth PG, Stroink H, et al. Leukoencephalopathy with swelling and a discrepantly mild clinical course in eight children. Ann Neurol 1995;37:324-334.

2. Schiffmann R, van der Knaap MS. Invited article: an MRIbased approach to the diagnosis of white matter disorders. Neurology 2009;72:750-759. 


\section{Neurology}

\section{Teaching NeuroImages: Megaloencephalic leukoencephalopathy with subcortical cysts (Van der Knaap disease) \\ Paramdeep Singh, Kavita Saggar, Archana Ahluwalia, et al. Neurology 2011;76;e34 \\ DOI 10.1212/WNL.0b013e31820d8b2f}

This information is current as of February 21, 2011

$\begin{array}{ll}\begin{array}{l}\text { Updated Information \& } \\ \text { Services }\end{array} & \begin{array}{l}\text { including high resolution figures, can be found at: } \\ \text { http://n.neurology.org/content/76/8/e34.full }\end{array} \\ \text { References } & \text { This article cites } 2 \text { articles, } 1 \text { of which you can access for free at: } \\ \text { http://n.neurology.org/content/76/8/e34.full\#ref-list-1 } & \\ \text { This article, along with others on similar topics, appears in the } \\ \text { following collection(s): } \\ \text { All Imaging } \\ \text { http://n.neurology.org/cgi/collection/all_imaging } \\ \text { All Pediatric } \\ \text { http://n.neurology.org/cgi/collection/all_pediatric } \\ \text { Developmental disorders } \\ \text { http://n.neurology.org/cgi/collection/developmental_disorders } \\ \text { MRI } \\ \text { http://n.neurology.org/cgi/collection/mri } \\ \text { Information about reproducing this article in parts (figures,tables) or in } \\ \text { its entirety can be found online at: } \\ \text { http://www.neurology.org/about/about_the_journal\#permissions } \\ \text { Information about ordering reprints can be found online: } \\ \text { Pttp://n.neurology.org/subscribers/advertise }\end{array}$

Neurology ${ }^{\circledR}$ is the official journal of the American Academy of Neurology. Published continuously since 1951, it is now a weekly with 48 issues per year. Copyright Copyright (C) 2011 by AAN Enterprises, Inc.. All rights reserved. Print ISSN: 0028-3878. Online ISSN: 1526-632X.

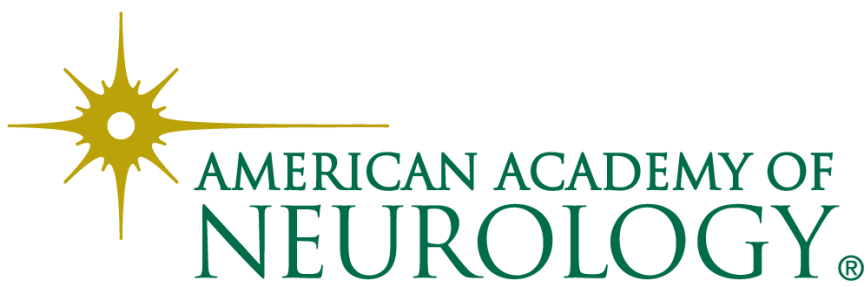

